\title{
The Taxation of Families: How Gendered (De)Familialization Tax Policies Modify Horizontal Income Inequality
}

\author{
MANUEL SCHECHTL
}

Humboldt-Universität zu Berlin, Berlin, Germany email: manuel.schechtl@hu-berlin.de

\begin{abstract}
A welfare state's tax system does not solely redistribute from rich to poor (vertical) but also between family types (horizontal). Different types of families are treated differently due to gendered (de)familialization policies in the tax code, such as joint filing for spouses or singleparent relief. In this study I aim to examine the tax system's modification of horizontal income inequality between the six most prevalent family types of non-retiree households. To answer my research aim I draw on harmonized data from 30 countries provided by the Luxembourg Income Study (LIS). I estimate pre- and post-fiscal income inequality measured as betweenfamily-type Theil indices. Using multivariate linear regression, I examine the association of the percentage change in inequality and the prevalence of family type-related tax characteristics. The results show that welfare states with familialization tax policies reduce less horizontal income inequality compared to welfare states without familialization tax policies. As familialization tax policies provide additional benefits for breadwinners with dependents, they discourage labour market participation of secondary earners and might exacerbate gender inequalities.
\end{abstract}

Keywords: family; inequality; redistribution; social policy; taxation; welfare state

\section{Introduction}

In the light of the ongoing scientific discussion on rising inequality, many scholars have called for the welfare state to intervene. However, welfare states differ in many aspects. Among the most influential topics in the literature is the welfare state's effort to redistribute from rich to poor in order to reduce poverty and inequality. Welfare states undertake redistribution through transfers and taxes (Prasad and Deng, 2009). Nevertheless, welfare states do not solely redistribute from rich to poor (vertical) (Bergh, 2005) but also between groups, such as gender, race or different family types (horizontal) (Stewart, 2008). Different types of families (defined by marital status and the presence of children) may be treated differently because tax systems provide family type-dependent benefits, including child allowances, marriage premiums or preferential tax schedules. However, if family-related aspects in the tax code systematically benefit those family types that have a higher income (e.g. married couples) compared to those with a lower 
income (e.g. single parents), then the reduction in income inequality between these family types may be lower than expected.

In general, the traditional married family pattern is commonly associated with positional advantages when compared to other family formations (Maldonado and Nieuwenhuis, 2015). Married couples tend to have higher disposable household incomes and low poverty rates, while single-parent families are associated with a higher risk of being poor (McLanahan and Percheski, 2008). If marriage is, for instance, associated with substantial institutionalized economic advantages, such as favourable tax brackets, single parents are systematically excluded from those benefits and gains. Hence, the horizontal redistribution system may hint at implicit political and social norms towards certain family formations (McCaffery, 1999). It is therefore crucial to learn more about the welfare state's mitigation of horizontal inequality. In other words, the institutionalized structuring of horizontal income inequality between family types matters because social risks are not distributed equally across family types.

These policies of horizontal redistribution, however, may encourage de-familialization by enhancing individual autonomy (e.g. single-parent allowance) or promote familialization through strengthening individual dependency on the family (e.g. joint taxation). Familialization tax policies disincentivize labour market participation of secondary earners and are, hence, associated with a traditional division of labour that exacerbates gender inequalities (Dingeldey, 2001). The modification of inequality between household types that is due to familialization tax policies is implicitly a question of gender inequality. If family formations with a traditional division of labour are systematically privileged by tax benefit policies, the distributive outcomes are gendered as well. In addition, these policies vary greatly across countries (Bussolo et al., 2019). Nevertheless, previous research has widely neglected the significance of tax policy as a means of social policy (Ruane et al., 2020). Therefore, the present study aims to understand how income taxation modifies horizontal income inequality between family types in a cross-national comparative perspective.

To answer my research aim, I examine income inequality between the six most prevalent family types (married without children, married with children, unmarried without children, unmarried with children, single parent, single) of non-retiree households before and after income taxation across welfare states. To this end, I draw on harmonized income and tax data from 30 countries in the Luxembourg Income Study (LIS) and estimate between-family-type Theil indices as measures of inequality before and after deducting income taxes. In order to assess how welfare states' tax policies structure income inequality between family types, I empirically identify family-related tax policies and evaluate their impacts using linear regression.

In the present study I build on the concept of 'horizontal inequality' from public and development economics and apply it to fiscal sociology. Broadly, 
horizontal inequality can be understood as any social, political or economic dimension of inequality between defined groups and thus it allows for adaptation to any structural dimension (Gachet et al., 2019). Hence, horizontal inequality generally refers to inequality between countries, regions or ethnicities (Stewart, 2008). The approach of horizontal inequality between family types emphasizes inequality as an outcome, which is structured by treating different family types differently.

Previous research studying income redistribution across welfare states has tended to neglect horizontal inequality and inequity, rendering it the 'orphan child of tax policy' (Gravelle and Gravelle, 2006). On the one hand, the comparative redistribution literature examines tax systems across welfare states in general (Prasad and Deng, 2009) and studies their inter-individual distributional effort (Kammer et al., 2012), or its development over time (Caminada et al., 2019). On the other hand, the body of literature interested in horizontal family-type redistribution usually singles out poverty (Brady et al., 2017b) and hence only looks at a very specific aspect of inequality. Notably, some recent studies highlighted the significance of tax benefits for redistribution (Coady et al., 2019). However, few studies directly compare between-family-type inequality, typically through referring to hypothetical households using a microsimulation model (Immervoll, 2011). In response, the present study aims to bridge the gap between the extensive comparative literature on the effect of taxation on vertical inter-individual inequality and the limited research on between-family-type redistribution.

This study contributes to our understanding of familialization tax policy in general and the welfare state's modification of horizontal income inequality in particular. Assessing the role of taxation as an institutional set-up that assigns additional benefits to certain family patterns is of considerable societal interest. Indeed, if being a member of a certain family type is associated with salient disadvantages, both economic and social well-being are affected. Therefore, I argue that because family patterns have become increasingly diverse in recent decades, inequality between family types has become a significant dimension of horizontal inequality. If different family types are treated differently due to their family status, then redistribution is not just about the individual's success in the labour market, but his or her embeddedness in family formations as well. In the following, I will briefly discuss previous research regarding family types in general (2.1) before addressing the specific literature on vertical (2.2) and horizontal inequality and redistribution (2.3).

\section{Background}

\subsection{Family types and taxation}

The overall effects of taxes on horizontal income inequality between family types may differ from those on vertical income inequality for two reasons. The 
first is related to patterns of dispersion of household-type income: the incomes of different family types are not equally distributed across the overall income strata, as single-parent households (for instance) usually cluster around lowincome levels (Alper et al., 2020). The second owes to the specific design of a welfare state's tax and transfer system, because married couples (for instance) may be treated differently from non-married couples. In particular, the formerly hegemonic married family household type may enjoy distributional benefits in some welfare states because of the rigidness of tax systems that still promote traditional male breadwinner family arrangements (McCaffery, 1999, p. 1).

However, between-family-type income inequality has come into view only due to the increasing diversification of family formations in recent decades. As long as the traditional married family pattern of the post-war era was the default social norm, diverging living arrangements seemed insignificant. Unsurprisingly, it has been scholars in the gender studies tradition who have drawn attention towards horizontal family-type redistribution in order to understand implicit gender inequalities in social policy (Sainsbury, 1999; Sainsbury, 2008). In particular, the ongoing debate about the 'marriage bonus' or 'single penalty' in the United States (US) tax system constitutes the majority of the literature (Alm and Leguizamon, 2015). Ultimately, research on the direct link between horizontal inequality and taxation remains dominantly interested in the interaction of tax benefits and labour market participation (Bick and Fuchs-Schündeln, 2018; Buettner et al., 2019; Dingeldey, 2001; Figari et al., 2011).

\subsection{Vertical inequality and redistribution}

Addressing the welfare state's contribution to inter-individual inequality by examining redistribution from high to low income is the most common approach in the literature. A large body of research studies the effects of taxes and transfers on individual income in a comparative setting (Immervoll, 2011; Jesuit and Mahler, 2010; Mahler and Jesuit, 2006). The general procedure is to capture 'redistribution' by calculating the difference between disposable income after taxes and transfers and market income before any public redistribution intervention. Although it has been noted that market income is itself shaped by the welfare state (Brady et al., 2017a; Bergh, 2005) - for instance, through minimum wage regulations - this 'from-gross-to-net'-approach is still the most common way to address redistribution (Guillaud et al., 2019).

Due to the greater availability of comparative data at the micro level with the expansion of the LIS database, comparative research on inequality due to taxes and transfers has recently become far more feasible. Hence, a growing body of literature investigates the distributional consequences of taxes and transfers in a comparative setting, emphasizing e.g. inequality over time (Wang et al., 2014), disentangling taxes and social benefits (Wang et al., 
2012), or stressing the relevance of different levers of the public distributional system (Guillaud et al., 2019).

\subsection{Horizontal inequality and redistribution}

The tax and transfer system treats individuals as situated and embedded in their living context, i.e. the household in which they live. Hence, almost all welfare states provide some kind of special transfers for children, tax exemptions for families or bonuses for married couples and so on. This is implicitly reflected in the literature on vertical inequality, but not systematically examined. Social science research on the vertical redistributive patterns of welfare states therefore misses a crucial dimension of redistribution: the redistribution of income between different types of families across strata. It is clear that tax systems do not treat everyone equally (given progressive taxation), but they may not even treat equal earners equally if one household receives tax relief and another does not.

The limited body of research examining between-family-type income inequality in most cases remains on a national case study basis (see e.g., Wrohlich et al., 2005). These studies usually emphasize the crucial significance of redistribution between types of families and lament the lack of attention given to the topic in the literature (Gravelle and Gravelle, 2006; Bussolo et al., 2019). Comparative studies tend to be based on microsimulation models with hypothetical median households (Immervoll, 2011) reporting median values or average tax rates (Pechman and Engelhardt, 1990). Across countries, changes in tax benefit policies in the past decades seemed to be more progressive for households with children than for singles (Immervoll, 2011).

A second strand of the between-family-type income inequality literature singles out poverty and its mediation. This sociological tradition looks at the reduction of the risk of poverty by the tax and transfer system and differences between family types (Rothwell and McEwen, 2017). In particular, some studies emphasize the significance of child poverty policies for differences in poverty rates between types of families (Gornick and Smeeding, 2018). David W. Rothwell and Annie McEwen (2017) focus on changes in child poverty risk by family types across liberal welfare states during the 2008 recession. By decomposing changes in child poverty over time, they illustrate the crucial impact of transfer and tax policies.

Recently, scholars began to address the redistributive impact of different tax benefit policies more thoroughly, highlighting the variation in fiscal redistribution across countries (Coady et al., 2019). These studies emphasized the relevance of tax benefits for social policy (Morel et al., 2018) or document their redistributive nature on a case study basis, indicating that tax benefits have been previously underestimated (Morel et al., 2019). Scrutinizing the effects of tax allowances and tax credits on household income across European countries, 
Avram concludes that redistribution through tax allowances is limited and often benefits middle and higher income households (2018). Consistently, Stebbing and Spies-Butcher find that tax benefit policies often invert the progressive income tax schedule, particularly so for middle income households (2010). These recent advances in research, however, address horizontal inequality between family types only implicitly.

It is worth noting, however, that horizontal family type redistribution analysis is not an alternative to vertical redistribution analysis, but merely offers a different perspective on inequality. If different family types are treated differently, then redistribution is not just about the individual's success in the labour market, but also his or her embeddedness in family formations. In the following I will therefore briefly elaborate on the main family-related tax characteristics.

\section{Tax mechanisms}

In this section I briefly describe the main concepts that underlie taxation-based income inequality between family types. An examination of overall tax indicators such as tax revenue or tax progressivity (see, for instance, Prasad and Deng, 2009), as can be found in the existing literature, may prove a poor indicator when it comes to between-family-type inequality modifications because these indicators can't take the specific tax treatment of certain family formations (for instance, special allowances for single parents) into account. I therefore argue that family-related components of the income tax system are pivotal. This draws attention to the tax benefit mechanisms within the tax system that are designed to promote certain family formations, such as tax reliefs for married couples. Such an idea of familialization in the tax code is by no means new (Sainsbury, 1999). Notwithstanding, little empirical evidence has been gathered (Figari, 2015).

In general, familialistic policies emphasize and enforce the caretaking responsibility of the family, whereas de-familialistic policies advocate the welfare state's responsibility to do so. However, both concepts should be understood as extremes on a continuum. Hence, the concept of familialization stresses the institutionally driven dependency of individuals on their family context, which is particularly interesting when scrutinizing income inequality between family types (Sainsbury, 1999). For example, policies promoting familialization may be defined as promoting a single-breadwinner model with a stay-at-home spouse (Rastrigina and Verashchagina, 2015; Leitner, 2003).

According to relationship status and the presence of children, the following six family types account for the vast majority of people in most countries: (1) married without children, (2) married with children, (3) unmarried without children, (4) unmarried with children, (5) single parent and (6) single. Nevertheless, how are patterns of tax policy associated with the modification 
of income inequality between these types of families? To scrutinize these structures, the specific design of a welfare state's tax system is pivotal. There are at least six different aspects within the income tax code that are highly relevant for income inequality modification between family types.

First, the overall level (1) of taxation indicates the distributional power: if there is no noteworthy income tax, redistribution may be insignificant. Second, the overall progressivity (2) of the tax structure may hint at its capacity to reduce market income inequality. Both tax level and tax progressivity are crucial for vertical and horizontal redistribution alike.

The specific notion of family type inequality, however, comes particularly into sight when scrutinizing the remaining four aspects. Unlike other instruments of fiscal welfare (for instance, tax deductions for mortgage interests) these tax benefits are by design tied to the marital status and the household composition. First, countries differ in the income tax filing unit (3), which most commonly is the individual or the married couple. The joint filing of married couples assumes that income and consumption are shared within the household and, in effect, means that the marginal income tax rate is dependent on the spouse's earnings. Therefore, joint filing has been criticized as a strong familialization policy that leads to persistent gender inequalities (McCaffery, 2009). Applying individual filing means that all individuals are treated separately regardless of their marital status when assessing the income tax. This is usually understood as a de-familialization policy design in the tax code, because it assumes the complete independence of individuals within households (Sainsbury, 1999).

Second, income splitting (4) aggregates the spouse's income and calculates the tax burden on the combined income. In other words this means that married couples can aggregate their income and split it equally across both tax-payers, potentially benefitting from lower marginal tax rates. Therefore, this is in fact a particularly strong version of joint filing. In most countries, married couples benefit from income splitting if they have unequal incomes (e.g. US and Germany). Therefore, strong incentives for the weak labour market attachment of secondary earners are commonly assumed (Rastrigina, Verashchagina, 2015; Alm, Melnik, 2004). The significant implications for gender inequality and individual autonomy have been widely discussed (McCaffery, 1999).

Although most welfare states apply individual filing, this does not mean that the tax rates of spouses are independent from each other, nor does it mean that family-oriented mechanisms are absent in the tax code. Many countries with individual filing at least offer some kind of special dependent spouse allowances (5) for the breadwinner (Rastrigina and Verashchagina, 2015). This mechanism reduces the taxable income of the main earner if his or her spouse has no or low income and hence promotes the dependencies of non-earner 
or stay-at-home spouses. Consequently, these tax characteristics are best described as familialization tax policies.

On the other hand, special single-parent allowances (6) reduce the tax burden for single parents. In contrast to the tax mechanisms mentioned above, such allowances are designed to secure a single parent's autonomy instead of binding it to the ex-spouse's alimony. Hence, it represents a de-familialization tax policy.

Taken together, the country-specific design of joint filing, the specific case of income splitting and the offer of dependent spouse allowances are implicit indicators of the degree of familialization in a welfare state's income tax system. Although in many countries there are additional characteristics that can be used to evaluate familialization in the tax code (e.g. the degree of transferability of basic allowances between spouses), the six aspects described above should be key mechanisms. These specific family-related aspects in the tax code should therefore influence inequality between types of families. In particular, married couples and couples with children are expected to benefit from familialization policies when compared to other family types.

\section{Hypotheses}

The overall income tax rate and the progressivity of the tax scheme are key determinants of income inequality modifications regardless of any specifically family-related income tax benefits. Given that different family types are distributed differently across income strata, progressive income taxation at a significant rate will result in a decrease of between-family-type income inequality after taxation. Hence, I derive my first hypotheses:

H1a (tax structure): Greater progressivity is associated with a higher reduction in income inequality between family types.

$H_{1} b$ (tax level): The higher the effective tax rate, the greater the reduction in income inequality between family types.

However, considering that most countries apply a specific tax treatment for different family formations, progressivity and tax level are not the sole determinants of income inequality modification. As mentioned above, several familyrelated benefits within the income tax schedule may change the picture dramatically. Family types with on average higher market incomes should in particular benefit from these family-related tax instruments. Therefore, these familialization tax policies may actually counteract the reduction of income inequality due to tax level and tax progressivity. Accordingly, I derive my second hypothesis:

$\mathrm{H}_{2}$ (tax benefits): Familialization policies in the tax code are associated with less reduction of between-family-type income inequality.

If the macro-level outcomes of the modification of between-family-type income inequality owe to the family-related tax benefits described above, then 
compared to other family types, the promoted family models (such as married couples) should face substantially lower tax burdens in countries with joint filing and income splitting for married couples. This should result in less reduction of inequality between married couples and all other family types. Therefore, I expect:

$\mathrm{H}_{3}$ (married couples): Joint filing and income splitting are associated with less reduction of income inequality between married couples and all other family types.

\section{Data}

To test my hypotheses, I draw on survey data from the LIS database. LIS is a cross-national collection of national microdata sets containing comprehensive data on income and their disaggregation into multiple sources, such as public transfers, taxes and labour income. The LIS data are particularly appropriate as they provide harmonized and hence comparable information on taxation at the household level. Given that it is not possible to distinguish income taxes from payroll taxes in most countries, both categories are analyzed together. For a consistent comparison, I use the last available data set for each country with gross income information, resulting in data from 30 countries. With the exception of the Belgium data, most of the data sets are from between 2013 and 2016. Due to the lack of data availability of the independent variables the analysis is restricted to a cross-sectional approach.

This study scrutinizes income inequality between the six most prevalent family types. It is worth noting, however, that households that do not fit into this categorization (such as living with other relatives) are excluded from the analysis. In most countries these six family nuclei account for almost all households (e.g. most European countries), but in some places (e.g. many Latin American countries) a considerable share of households is excluded due to more complex family arrangements. ${ }^{1}$ Therefore, income inequality between family types always refers to income inequality between these six common family nuclei. Additionally, I restrict my sample to households without any pension income due to substantial cross-country differences in the tax treatment of pension income.

Monetary information is adjusted to 2011 USD purchasing power parity. Furthermore, households are weighted using the LIS weights to improve the representability of countries. Ultimately, all income information is equalized according to the standard LIS procedure, which divides the household income by the square root of the number of household members. 


\section{Measurement}

\subsection{Dependent variable}

Following Huber and Stephens (2014, p. 252), I measure redistribution as the percentage reduction in inequality, instead of measuring the absolute reduction. The measurement of change in inequality therefore equals:

$$
\Delta \mathrm{I}=\frac{I_{\text {pre }}-I_{\text {post }}}{I_{\text {pre }}} * 100
$$

where $I_{\text {pre }}$ refers to inequality before and $I_{\text {post }}$ to inequality after subtracting income taxes. Most literature on redistribution examines the percentage change in the Gini index. When it comes to inequality between groups, however, inequality measures such as the Theil index are superior because of their additive nature (Jenkins and van Kerm, 2009). Most notably, the Theil index allows for decomposition in within- and between-group components and hence perfectly fits the examination of inequality between family types. This means that the overall inequality measure equals the aggregation of the inequality measured between groups and the inequality measured within groups. The within-group component therefore indicates e.g. the unequal distribution of income between all single-parent households. The between-group component in this example, however, shows the unequal distribution of income, e.g. between all singleparent households and all married couples. Therefore, there is only one between-group inequality value per country. Technically, the between-group component of the Theil index measures the sum of the weighted log ratio of the different groups' population and income shares. Hence, the between-group Theil index can be expressed as follows:

$$
\mathrm{T}=\sum w_{g} * \ln \left(\frac{w_{g}}{p_{g}}\right)
$$

Where $w_{g}$ corresponds to group g's share of total income and $p_{g}$ indicates group g's population share. The between-group component equals zero if a group has equal income and population shares. In other words, this means that the between-group Theil index measures the sum of the deviation of each group from its fair share. Therefore, this between-group measure does not indicate anything about inequality within the group. Because different indices have different levels of sensitivity to distinct parts of the distribution, I discuss the results from the Theil index in the main analysis and provide the mean log deviation (MLD) results in the appendix. I use the Stata ado ineqdeco for the inequality decomposition (Jenkins, 1999). 


\subsection{Independent variables}

I calculate the mean effective tax rate per country from the LIS data. This overall level of income tax indicates the mean income tax rate for a given country, regardless of any family-type specification. In addition, I address tax progressivity by calculating the Suits index (Suits, 1977). Based on the Lorenz curve, this index measures progressivity (or regressivity) as the deviation from proportional taxation.

Information on family-related tax characteristics is derived from the Organisation for Economic Co-operation and Development country information (OECD, 2000-2016). Similar approaches trying to code the OECD country report information into a comprehensive data set have been undertaken by Bettio and Verashchagina (2009) and Rastrigina and Verashchagina (2015), although for different points in time. In order to gather information from countries outside the OECD, a small online survey of national experts was conducted by the author. National experts were asked if certain family-related tax policies exist in their country in the year of observation. The information refers to each country's LIS data set year and has been made freely accessible through the OpenScienceNetwork by the author. ${ }^{2}$

The prevalence of joint filing indicates if married couples are usually treated jointly regarding their income tax assessment. In some countries, this can also apply for unmarried couples. However, many countries with default joint filing have optional individual filing. The existence of joint filing does not necessarily say anything about the effective tax treatment and its economic outcome, this depending on the country-specific design of joint filing. Nevertheless, it usually hints at the potential beneficial treatment of married couples and familialization in the tax code. Income splitting is essentially the most radical version of joint filing. By aggregating the couple's incomes and calculating the tax burden on the total income, it establishes complete dependency between spouses regarding the income tax. However, although detailed schedules vary greatly across countries, in most cases unequally earning couples benefit. In addition, dependent spouse allowance prevalence provides information about additional tax deductions for having a non-working or low-paid dependent spouse. It is worth noting, however, that in effect joint filing and income splitting (for instance) can have similar or more severe consequences regarding the tax burden. In addition, the possibility of transferring unused own basic tax relief to the spouse functions somewhat similarly in many cases. Therefore, many other tax characteristics could provide some kind of 'hidden jointness' of couples. Lastly, single-parent allowances capture the beneficial treatment of single parents in the tax code. Table 1 shows the discussed tax characteristics for each country, sorted by their corresponding welfare state types. 
TABLE 1. Tax characteristics per country

\begin{tabular}{|c|c|c|c|c|c|c|}
\hline Country & Tax rate $(\%)$ & Suits index & Joint filing & Income splitting & Dependent spouse allowance & Single-parent allowance \\
\hline \multicolumn{7}{|l|}{ Social-democratic } \\
\hline Denmark & 36.74 & .027 & & & & yes \\
\hline Finland & 28.68 & .062 & & & & \\
\hline Iceland & 30.59 & .057 & & & & \\
\hline Norway & 29.09 & -.015 & yes & yes & & yes \\
\hline Sweden & 32.76 & .036 & & & & \\
\hline \multicolumn{7}{|l|}{ Conservative } \\
\hline Austria & 30.01 & .117 & & & yes $^{1}$ & yes \\
\hline Belgium & 36.26 & .092 & yes $^{2}$ & yes & yes & yes \\
\hline Germany & 32.94 & .075 & yes $^{3}$ & yes & & yes \\
\hline Luxembourg & 26.61 & .099 & yes & yes & & yes \\
\hline Netherlands & 35.64 & .061 & & & yes $^{4}$ & yes \\
\hline \multicolumn{7}{|l|}{ Liberal } \\
\hline Canada & 22.50 & .122 & & & yes & yes \\
\hline Ireland & 26.36 & .206 & yes & yes & yes & yes \\
\hline Switzerland & 30.36 & -.001 & yes & 5 & yes & yes \\
\hline United Kingdom & 20.79 & .105 & & 6 & & \\
\hline United States & $24 \cdot 32$ & .162 & yes $^{7}$ & yes & & \\
\hline \multicolumn{7}{|l|}{ Eastern-European } \\
\hline Czech Republic & 18.63 & .100 & & & yes $^{8}$ & \\
\hline Estonia & 18.22 & .038 & yes & & & \\
\hline Lithuania & 17.69 & .011 & & & & \\
\hline Slovakia & 16.11 & .035 & & & yes $^{9}$ & \\
\hline \multicolumn{7}{|l|}{ Mediterranean } \\
\hline Greece & 25.01 & .114 & 10 & & & \\
\hline Israel & 20.07 & .247 & & & & yes \\
\hline
\end{tabular}


TABLE 1. Continued

\begin{tabular}{|c|c|c|c|c|c|c|}
\hline Country & Tax rate $(\%)$ & Suits index & Joint filing & Income splitting & Dependent spouse allowance & Single-parent allowance \\
\hline Italy & 27.87 & .199 & & & yes & yes $^{11}$ \\
\hline Spain & 19.02 & .172 & yes & & & \\
\hline \multicolumn{7}{|l|}{ Latin-American } \\
\hline Brasil & 11.02 & .293 & yes $^{12}$ & & yes & \\
\hline Colombia & 06.58 & .315 & & & & \\
\hline Dominican Republic & 02.47 & .338 & yes $^{13}$ & & & \\
\hline Guatemala & 14.53 & .211 & & & & \\
\hline Panama & 11.04 & .225 & yes & & & \\
\hline Peru & 04.87 & .346 & & & & \\
\hline \multicolumn{7}{|l|}{ Other } \\
\hline South Africa & 24.81 & .246 & & & & \\
\hline
\end{tabular}

Notes: ${ }^{1}$ Sole-earner allowance if the spouse's income is below a given threshold.

${ }^{2}$ Joint filing is mandatory for married couples.

${ }^{3}$ Joint filing is the default for married couples. Full income splitting is more advantageous if spouses have different incomes.

${ }^{4}$ This is an income dependent combination credit for spouses.

${ }^{5}$ Regarding the federal tax there is a basic deduction for married couples.

${ }^{6}$ Spouses might transfer up to ten percent of their personal allowance to the partner.

${ }^{7}$ The tax unit is the individual but couples have the option to file jointly. If married spouses file jointly, the phasing out of the personal exemption is below double the individual scheme.

${ }^{8} \mathrm{~A}$ tax credit if the spouse has income below a certain threshold.

${ }^{9}$ Additional allowance if the spouse's income is below a certain threshold. Therefore coded as dependent spouse allowance.

${ }^{10}$ Spouses are required to submit a joint tax return but are taxed individually. Therefore not coded as joint filing.

${ }^{11}$ Single-parents get a child allowance equal to the maximum of a married couple's dependent spouse and child allowance.

${ }^{12}$ Dependent spouse allowance is possible if spouses choose the optional joint filing, which is more advantageous if the dependent spouse has a low income.

${ }^{13}$ Spouses file jointly unless the women demonstrates her own income. 


\section{Method}

I estimate the following multivariable linear regression model:

$$
y_{i}=\beta_{0}+\beta_{1} x_{1}+\beta_{2} \text { tax }_{\text {level }}+\beta_{3} \text { tax progressivity }_{i}+\varepsilon_{i}
$$

where $y_{i}$ refers to the income inequality modification between family types, measured as the percentage change in between-group Theil index and $x_{1}$ denotes the tax characteristics from Table 1. Notably, the dependent variable itself is already an estimation. Therefore, my method is best described as an estimated dependent variable approach (Lewis and Linzer, 2005). Especially with small sample sizes, such two-stage estimation procedures can prove to be a valuable option. As an additional advantage, coefficients are easy to interpret (Nelson, 2009). All estimates of standard errors and confidence intervals are derived using the bootstrap (reps $=1000){ }^{3}$

I aim to explain differences across countries by regressing the modification of income inequality on the tax indicators described in the previous sections. All results are presented without additional controls and with controls for tax level and tax progressivity. Due to the small sample size $(n=30)$, combining all indicators into one model does not seem to be a suitable option. Therefore, the interpretation of the results focuses on separate models for each tax characteristic.

\section{Results}

I begin with empirically testing my first hypothesis. As discussed above, the effective tax rate (level) and the progressivity of the tax schedule should be positively associated with the reduction of between-family-type income inequality. Therefore, I use the change in inequality that is due to taxation measured as the percentage change in the Theil index as the dependent variable and regress it on the mean effective tax rate and the Suits index for every country. Figure 1 presents the coefficients of the respective ordinary least squares (OLS) regressions.

As Figure 1 indicates, a higher level of taxation is associated with a greater reduction in inequality between family types, as expected in the first hypothesis. The correlation is statistically significant and increases when the progressivity index is added to the model. Against my expectations, however, the measure for tax progressivity is neither statistically significant nor has any explanatory power on its own. This may point to the relevance of family-related tax benefits that disturb the relationship between progressivity and inequality when looking at between-family-type inequality. In general, progressive taxes are most prevalent in the Latin American countries with overwhelmingly low tax rates. Hence, effective tax rate and tax progressivity are negatively associated (for a graphical clarification, see Figure A1 in the appendix). Therefore, the most progressive tax systems in the sample have the weakest redistributional power due to their low 


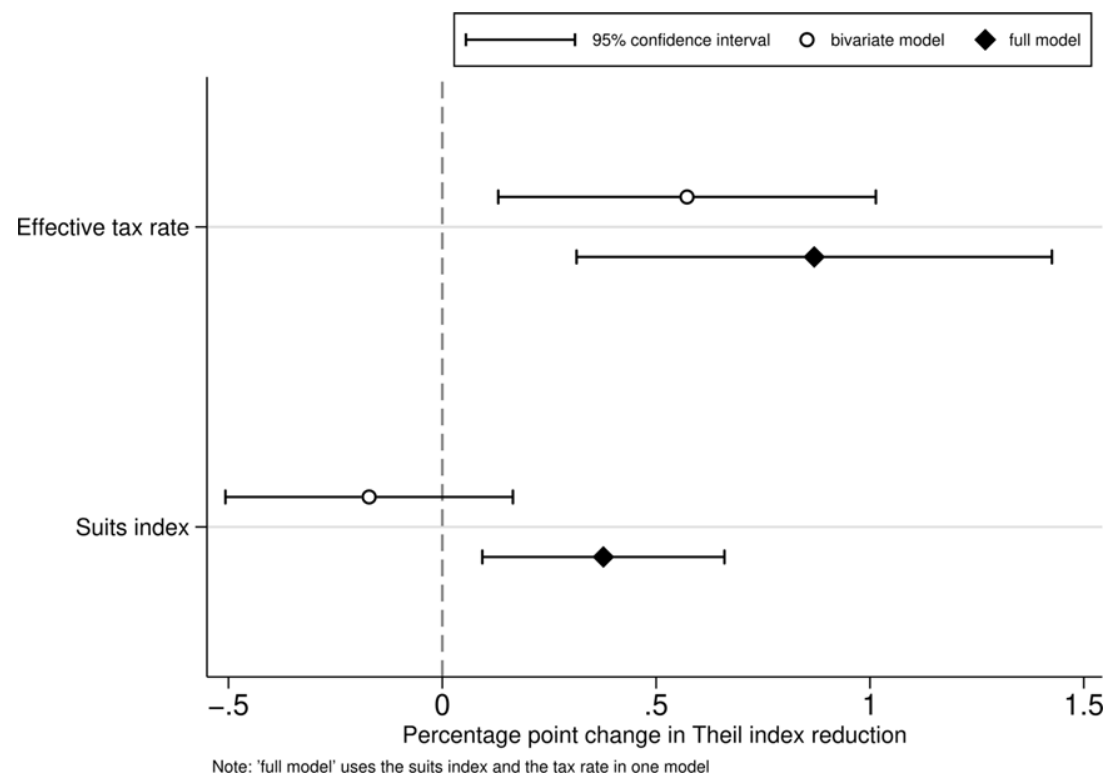

FIGURE 1. Linear regression on the Theil index percentage change (tax structure)

tax rates. This may explain the lack of explanatory potential of tax progressivity on its own. Once the effective tax rate is included, however, the progressivity index becomes positive and statistically significant, as expected.

In order to test my second hypothesis, I include dummies for the family tax benefit characteristics from Table 1. I expected a negative relationship between the Theil index and familialization policies (i.e. joint filing, income splitting, dependent spouse relief) and a positive one for single-parent allowances. When the dummies are included, tax level and progressivity are always positively correlated with the reduction in income inequality between family types in all models (see Table A1 in the appendix for the full models). This may indeed hint at the role tax benefit policies play in interfering with tax progressivity. Figure 2 shows all separate models regarding the tax benefit coefficients, each with and without controlling for tax level and tax progressivity. The separate tax benefit dummy models, however, provide mixed evidence. First, all familialization characteristics have a negative coefficient once I include the controls. This is mostly in line with my expectation of decreased reduction in inequality between family types due to family-type-related tax benefits. Surprisingly and against my expectations, I find a negative coefficient for single-parent allowances, too. It is probable that many single-parent households have income levels below the basic relief or tax-free bracket and hence do not benefit much from their special allowance. However, not all characteristics are statistically significant. Hence, I find only weak evidence regarding the dependent spouse relief 


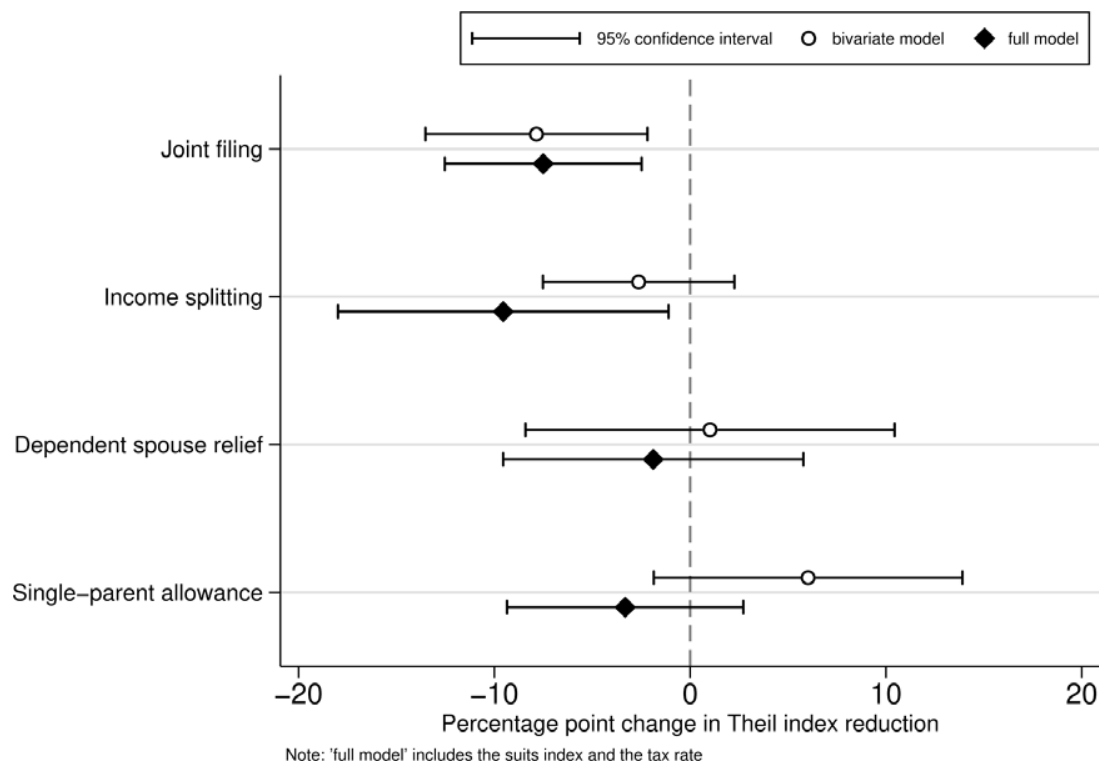

FIGURE 2. Linear regression coefficients of separate tax characteristics

and the single-parent allowance. Nevertheless, joint filing in general and income splitting in particular are strongly associated with a lower reduction in income inequality between family types. It is worth noting that the values of the coefficients are substantial. Controlling for tax level and tax progressivity, welfare states with joint filing reduce income inequality between family types almost eight percentage points less than countries with individual filing. This means that welfare states with joint filing have about half the inequality reduction of welfare states without it, when comparing predicted values.

In my third hypothesis, I single out married couples and examine income inequality between them and all other family types combined. This should provide indications if the modification of between-family-type inequality is exclusively driven by the special treatment of married couples. Figure 3 displays the linear regression results regarding the modification of income inequality between the two groups: married couples and others. In contrast to all previous models, progressivity and tax level are no longer significantly correlated with the reduction in between-group inequality (all details are provided in Table A2 in the appendix). This does indeed support the idea of tax benefits counteracting the general redistributional pattern of progressive income taxation. As Figure 3 shows, the dummies for dependent spouse relief and single-parent allowances do not provide much explanatory power. The dummy for joint filing is substantial and negative, yet alone not significant. The coefficient for income splitting, however, is more than three times as large and highly significant. 


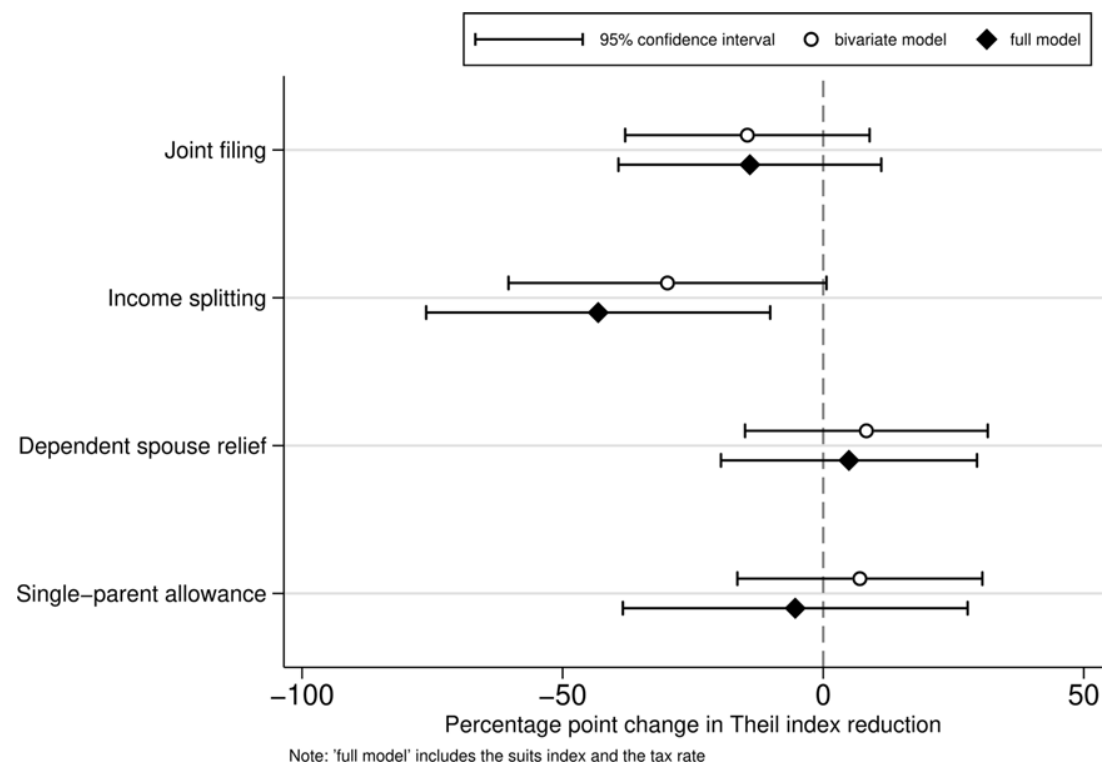

FIGURE 3. Linear regression coefficients of separate tax characteristics (married vs. others)

This indicates the significance of the tax treatment of married couples. However, the positive coefficient of dependent spouse relief in particular may suggest that the overall picture of between-family-type inequality is more complex than the treatment of married couples alone. Many countries provide tax allowances for dependent partners or let unmarried couples file jointly, just like married couples. Income splitting thus seems to be the one mechanism that is designed almost exclusively for married couples.

To evaluate the robustness of these findings, I replicate the main analysis with inequality measured as MLD (Figure $\mathrm{A}_{2}$ and $\mathrm{A}_{4}$ in the appendix) as well as with the OECD equivalence scale (Figure $A_{3}$ ). To assess if the findings are driven by outliers, I additionally run all models excluding one country each time (Figures $\mathrm{A}_{5}, \mathrm{~A}_{6}$ and $\mathrm{A}_{7}$ ). However, all additional analyses support the presented findings. Lastly, I address the relevance of familialization tax policies regarding overall vertical income inequality. As Figure A8 in the appendix indicates, the overall pattern is similar to what we have seen regarding horizontal inequality. The coefficients, however, are not significant. Nevertheless, this additional analysis suggests that welfare states with income splitting have about five percentage points lower vertical income inequality reduction. 


\section{Discussion}

In this study, I have investigated the relationship between income taxes and the modification of horizontal income inequality between family types using harmonized data from 30 countries in the LIS. I have argued that taxation is a genuine aspect of social policy, which merits the attention of sociologists interested in comparative welfare state research. Throughout the analysis it became evident that income taxation is an essential instrument of horizontal inequality modification. In line with my expectations, I showed that the average effective tax rate was positively correlated with the reduction in income inequality between family types. This also held for tax progressivity when controlling for tax level.

I then examined the role of familialization tax policies, which foster the individual's dependency on family context. These familialization policies in the tax code were found to be negatively associated with the welfare state's capacity to reduce income inequality between family types. As expected, joint assessment of married couples in general and income splitting in particular seemed to diminish the redistributional power substantially. The empirical findings suggest that the prevalence of joint filing cuts the tax-induced reduction in income inequality between types of families by almost half. On the other hand, de-familialization policies appeared to strengthen individual autonomy and mitigate inequality. However, I did not find consistent evidence that single-parent allowances enhance redistribution between family types.

These findings are consistent with previous research suggesting that tax allowance policies benefit middle and higher income households (Avram, 2018; Stebbing and Spies-Butcher, 2010). Inverting the progressive structure of the income tax, fiscal benefits for married couples at the upper income deciles reduce the distributive potential of income taxation. However, it seems that these familialization tax policies in general not only impede effective redistribution, but also hinder individual autonomy and gender equality (Orloff, 1993; Saraceno, 2016), but that, in the case of taxation, these policies may create inequalities between types of families at the same time. Welfare states without joint filing not only have significantly higher levels of between-family-type inequality reduction but greater individual autonomy due to individual filing as a critical de-familialization policy. At the country level, this interpretation may imply a lose-lose situation of family dependency and income inequality. In this context, the individual is thus confronted with economically beneficial family dependency at the cost of a loss of individual autonomy. As familialization policies provide additional benefits for breadwinners with dependents, they discourage more autonomous individual arrangements.

Second and as widely discussed within the literature on labour market incentives for secondary earners (Jara Tamayo and Popova, 2020), familialization policies in the tax code potentially hinder female labour market participation. The tax code promotes a strong breadwinner model in most countries with 
joint filing and progressive income taxation due to lower marginal tax rates for the primary earner. Again, while this is widely known to exacerbate gender inequality (Sainsbury, 1999; McCaffery, 2009), as the study at hand indicates, it is also associated with greater income inequality between family types at the macro level. In some countries, however, the beneficial treatment of married couples also applies to same sex couples implying similar incentives for their division of labour.

This study is limited in several ways. First, the countries were not selected randomly. Nevertheless, external validity should be substantial due to the diverse set of countries. Second, the dependent variable measures inequality between the six most prevalent family types, but this fits some countries better than others. In countries with a high share of multi-generational households, the findings do not reflect the actual situation of many families. Furthermore, population characteristics and cross-country differences in the reliance on social security contributions may lead to an underestimation of the relevance of tax benefits. Therefore, the relationship of interest may be stronger than indicated in this study. Lastly, information on taxes may be inaccurate. However, in the LIS, the tax information from the countries used in this study is mainly derived from register data and/or national microsimulations and should, hence, be sufficiently reliable.

The social and political implications are, however, manifold. As this article has shown, these tax mechanisms may foster horizontal inequality. In the light of rising inequality and escalating public debt, it is debatable whether these tax expenditures are desirable or affordable. For the public budget, tax benefits essentially represent a loss of revenue. Hence, the forgone tax revenue could be used for social transfers to the poor. In other words, politically these familialization tax policies seem to cut public revenue and foster inequality, while socially they appear to promote family dependency and a traditional division of labour.

This study contributes to our understanding of the consequences of institutionalized differences in the tax treatment of family types. It sheds light on the pivotal yet largely overlooked role of taxation when scrutinizing horizontal inequality between family types. Focusing on (de-)familialization tax policies with different consequences for inequality, this study emphasizes the role of family tax policy as a form of social policy.

\section{Funding}

Manuel Schechtl's research was funded by the Support Network for Interdisciplinary Social Policy Research (FIS) of the German Federal Ministry of Labour and Social Affairs. 


\section{Acknowledgements}

I would like to thank Philipp Lersch, Nicole Kapelle, Theresa Nutz, Daria Tisch, participants at the SASE, ECSR, ESPAnet and ASA annual conferences as well as participants at the colloquium for Sociology of Social Policy at Humboldt Universität zu Berlin for helpful comments and suggestions on earlier versions of the manuscript.

\section{Competing interests}

The author declare none.

\section{Supplementary material}

To view supplementary material for this article, please visit https://doi.org/10. $1017 /$ So047279421000404

\section{Notes}

1 The share of excluded households ranges from 0.65 percent in Sweden to 39.66 percent in South Africa. Besides the outlier of South Africa, only the Latin American countries have other household types of considerable magnitude (roughly 25 percent). The six family types, however, account for about 95 percent of all households in European countries.

2 Information available at: https://osf.io/8pe 7 b/

3 Figures A9, A10 and A11 replicate the main analysis with jackknife instead of bootstrap standard errors. Nevertheless, the results do not change substantially.

\section{References}

Alm, J. and Leguizamon, J. S. (2015), 'Whither the Marriage Tax?', National Tax Journal, 68, 2, 251-280.

Alm, J. and Melnik, M. I. (2004), 'Taxing the "Family" in the Individual Income Tax', Andrew Young School of Policy Studies.

Alper, K., Huber, E. and Stephens, J. D. (2020), 'Poverty and Social Rights Among the Working Age Population in Post-Industrial Democracies', Social Forces, 1-35.

Avram, S. (2018), 'Who benefits from the 'hidden welfare state'? The distributional effects of personal income tax expenditure in six countries', Journal of European Social Policy, 28, 3, 271-293.

Bergh, A. (2005), 'On the Counterfactual Problem of Welfare State Research: How Can We Measure Redistribution?', European Sociological Review, 21, 4, 345-357.

Bettio, F. and Verashchagina, A. (2009), 'Fiscal system and female employment in Europe', EGGE - European Network of Experts on Employment and Gender Equality issues.

Bick, A. and Fuchs-Schündeln, N. (2018), 'Taxation and Labour Supply of Married Couples across Countries: A Macroeconomic Analysis', Review of Economic Studies, $85,1543-1576$.

Brady, D., Blome, A. and Kleider, H. (2017a), 'How Politics and Institutions Shape Poverty and Inequality', in D. Brady, and L. M. Burton (eds.), The Oxford Handbook of the Social Science of Poverty, Oxford: Oxford University Press.

Brady, D., Finnigan, R. M. and Hübgen, S. (2017b), 'Rethinking the Risks of Poverty: A Framework for Analyzing Prevalences and Penalties', American Journal of Sociology, $123,3,740-786$.

Buettner, T., Erbe, K. and Grimm, V. (2019), 'Tax planning of married couples and intrahousehold income inequality', Journal of Public Economics, 179. 
Bussolo, M., Krolage, C., Makovec, M., Peichl, A., Stöckli, M., Torre, I. and Wittneben, C. (2019), 'Vertical and Horizontal Redistribution: The Cases of Western and Eastern Europe', Euromod Working Paper Series, 1, 1-35.

Caminada, K., Goudswaard, K., Wang, C. and Wang, J. (2019), 'Income Inequality and Fiscal Redistribution in 31 Countries After the Crisis', Comparative Economic Studies, 61, 1, 119-148.

Coady, D., D'Angelo, D. and Evans, B. (2019), 'Fiscal Redistribution and Social Welfare', IMF Working Papers, 51, 19.

Dingeldey, I. (2001), 'European Tax Systems and their Impact on Family Employment Patterns.', Journal of Social Policy, 30, 4, 653-672.

Figari, F. (2015), 'From Housewives to Independent Earners: How the Tax System Can Help Women to Work in a Context of Strong Familialism', Journal of Social Policy, $44,1,63-82$.

Figari, F., Immervoll, H., Levy, H. and Sutherland, H. (2011), 'Inequalities within couples in Europe: Market incomes and the role of taxes and benefits', Eastern Economic Journal, 37, $3,344-366$.

Gachet, I., Grijalva, D. F., Ponce, P. A. and Rodríguez, D. (2019), 'Vertical and Horizontal Inequality in Ecuador: The Lack of Sustainability', Social Indicators Research, 145, 3, $861-900$.

Gornick, J. C. and Smeeding, T. M. (2018), 'Redistributional Policy in Rich Countries: Institutions and Impacts in Nonelderly Households', Annual Review of Sociology, 44, 44, 441-468.

Gravelle, J. and Gravelle, J. (2006), 'Horizontal Equity and Family Tax Treatment: The Orphan Child of Tax Policy', National Tax Journal, LIX, 3, 631-649.

Guillaud, E., Olckers, M. and Zemmour, M. (2019), 'Four Levers of Redistribution: The Impact of Tax and Transfer Systems on Inequality Reduction', Review of Income and Wealth, 3, 1.

Huber, E. and Stephens, J. D. (2014), 'Income inequality and redistribution in post-industrial democracies: demographic, economic and political determinants', Socio-Economic Review, 12, 2, 245-267.

Immervoll, H. (2011), 'Redistribution Policy and Inequality Reduction in OECD Countries: What Has Changed in Two Decades?', LIS Working Paper Series, 572.

Jara Tamayo, H. X. and Popova, D. (2020), 'Second Earners and In-Work Poverty in Europe', Journal of Social Policy, 1-23.

Jenkins, S. (1999), Ineqdeco: Stata module to calculate inequality indices with decomposition by subgroup, Boston College Department of Economics.

Jenkins, S. and van Kerm, P. (2009), 'The Measurement of Economic Inequality', in W. Salverda, B. Nolan and T. M. Smeeding (eds.), The Oxford Handbook of Economic Inequality, Oxford: Oxford University Press, 40-67.

Jesuit, D. K. and Mahler, V. A. (2010), 'Comparing Government Redistribution Across Countries: The Problem of Second-Order Effects', Social Science Quarterly, 91, 5, 1390-1404.

Kammer, A., Niehues, J. and Peichl, A. (2012), 'Welfare regimes and welfare state outcomes in Europe', Journal of European Social Policy, 22, 5, 455-471.

Leitner, S. (2003), 'Varieties of familialism: The caring function of the family in comparative perspective', European Societies, 5, 4, 353-375.

Lewis, J. B. and Linzer, D. A. (2005), 'Estimating Regression Models in Which the Dependent Variable Is Based on Estimates', Political Analysis, 13, 4, 345-364.

Luxembourg Income Study (LIS), Database: http://www.lisdatacenter.org, (multiple countries; January 2020-September 2020) Luxembourg.

Mahler, V. A. and Jesuit, D. K. (2006), 'Fiscal redistribution in the developed countries: new insights from the Luxembourg Income Study1', Socio-Economic Review, 4, 3, 483-511.

Maldonado, L. C. and Nieuwenhuis, R. (2015), 'Family policies and single parent poverty in 18 OECD countries, 1978-2008', Community, Work \& Family, 18, 4, 395-415. 
McCaffery, E. (2009), 'Where's the Sex in Fiscal Sociology?: Taxation and Gender in Comparative Perspective', in I. W. Martin, A. K. Mehrotra and M. Prasad (eds.), The new fiscal sociology. Taxation in comparative and historical perspective, Cambridge: Cambridge University Press, 216-236.

McCaffery, E. J. (1999), Taxing women: How the Marriage Penalty Affects Your Taxes, 1999th edn, Chicago: University of Chicago Press.

McLanahan, S. and Percheski, C. (2008), 'Family Structure and the Reproduction of Inequalities', Annual Review of Sociology, 34, 1, 257-276.

Morel, N., Touzet, C. and Zemmour, M. (2018), 'Fiscal welfare in Europe: Why should we care and what do we know so far?', Journal of European Social Policy, 28, 5, 549-560.

Morel, N., Touzet, C. and Zemmour, M. (2019), 'From the hidden welfare state to the hidden part of welfare state reform: Analyzing the uses and effects of fiscal welfare in France', Social Policy \& Administration, 53, 1, 34-48.

Nelson, M. (2009), 'An application of the estimated dependent variable approach: Trade union members' support for active labor market policies and insider-outsider politics', International Journal of Public Opinion Research, 21, 2, 224-234.

OECD (2000-2016), Database: http://oecd.org/social/benefits-and-wages/, Benefits and wages country reports.

Orloff, A. S. (1993), 'Gender and the Social Rights of Citizenship: The Comparative Analysis of Gender Relations and Welfare States', American Sociological Review, 58, 3, 303-328.

Pechman, J. A. and Engelhardt, G. V. (1990), 'The Income Tax Treatment of the Family: An International Perspective', National Tax Journal, 43, 1, 1-22.

Prasad, M. and Deng, Y. (2009), 'Taxation and the worlds of welfare', Socio-Economic Review, $7,3,431-457$.

Rastrigina, O. and Verashchagina, A. (2015), Secondary earners and fiscal policies in Europe.

Rothwell, D. W. and McEwen, A. (2017), 'Comparing Child Poverty Risk by Family Structure During the 2008 Recession', Journal of Marriage and Family, 79, 5, 1224-1240.

Ruane, S., Collins, M. L. and Sinfield, A. (2020), 'The Centrality of Taxation to Social Policy', Social Policy and Society, 19, 3, 437-453.

Sainsbury, D. (1999), Gender and Welfare State Regimes, Oxford: Oxford University Press.

Sainsbury, D. (2008), 'Gendering the welfare state', in Goertz, G. and Mazur, A. G. (eds.), Politics, Gender, and Concepts. Theory and Methodology, Cambridge: Cambridge University Press, 94-113.

Saraceno, C. (2016), 'Varieties of familialism: Comparing four southern European and East Asian welfare regimes', Journal of European Social Policy, 26, 4, 314-326.

Stebbing, A. and Spies-Butcher, B. (2010), 'Universal welfare by other means? Social tax expenditures and the Australian dual welfare state', Journal of Social Policy, 39, 4, 585-606.

Stewart, F. (ed.) (2008), Horizontal inequalities and conflict: Understanding group violence in multiethnic societies, London: Palgrave MacMillan.

Suits, D. B. (1977), 'Measurement of Tax Progressivity', The American Economic Review, 67, 4, 747-752.

Wang, C., Caminada, K. and Goudswaard, K. (2012), 'The redistributive effect of social transfer programmes and taxes: A decomposition across countries', International Social Security Review, 65, 3, 27-48.

Wang, C., Caminada, K. and Goudswaard, K. (2014), 'Income redistribution in 20 countries over time', International Journal of Social Welfare, 23, 3, 262-275.

Wrohlich, K., Dell, F. and Baclet, A. (2005), 'Steuerliche Familienförderung in Frankreich und Deutschland', DIW Wochenbericht, 72, 33, 479-486. 